\title{
Feral children: settler colonialism, progress, and the figure of the child
}

\section{Toby Rollo}

To cite this article: Toby Rollo (2018) Feral children: settler colonialism, progress, and the figure of the child, Settler Colonial Studies, 8:1, 60-79, DOI: 10.1080/2201473X.2016.1199826

To link to this article: https://doi.org/10.1080/2201473X.2016.1199826

册 Published online: 29 Jun 2016.

Submit your article to this journal $\pi$

Џll Article views: 325

Q View related articles $\sqsubset$

View Crossmark data ¿

Citing articles: 1 View citing articles 5 


\title{
Feral children: settler colonialism, progress, and the figure of the child
}

\author{
Toby Rollo \\ Department of Political Science, University of British Columbia, Vancouver, BC, Canada
}

\begin{abstract}
Settler colonialism is structured in part according to the principle of civilizational progress yet the roots of this doctrine are not well understood. Disparate ideas of progress and practices related to colonial dispossession and domination can be traced back to the Enlightenment, and as far back as ancient Greece, but there remain unexplored logics and continuities. I argue that civilizational progress and settler colonialism are structured according to the opposition between politics governed by reason or faith and the figure of the child as sinful or bestial. Thus, it is not contingent, but rather necessary that justificatory frameworks of European empire and colonialism depict Indigenous peoples as children. To illustrate how the theoretical link between Indigenous peoples and children emerges not as a simple analogy, but rather, as the source of the premodern/modern and savage/civilized binaries, I trace the various historical iterations of the political/ childhood opposition through the classical, medieval, enlightenment, and modern eras. I show how the model of civilizational progress from a premodern and savage state of childhood continues to serve as the model for settler colonial exclusion and domination of Indigenous peoples.
\end{abstract}

\section{KEYWORDS}

Settler colonialism; progress; childhood; history of political thought

The violence of settler colonial dispossession and assimilation flows historically from civilizational precepts such as Manifest Destiny, terra nullius, the white man's burden and the Doctrine of Discovery. Although formally rejected by modern governments, these principles are nevertheless preserved in the legal and political systems of contemporary settler colonial states. The figure at the heart of these colonial doctrines is the 'Indian', often understood as an incarnation of the ancient Greek and Roman category of the foreign barbarian whose conquest was an enduring imperial ambition. ${ }^{1}$ Yet the conceptualization of the 'Indian' in the context of New World settler colonialism differs significantly from this classification. Whereas the category of the barbarian reflected an ancient imperial mandate to pursue glory through conquest and slavery, the idea of the 'Indian' is distinguished by the modern colonial mandates of civilizational progress through dispossession and education. I argue in the following that Indigenous peoples are not conceptualized primarily as barbarian opponents of empire, but rather, the 
'Indian' is constructed according to the ancient conception of the degraded, not fully human, child. In the following, I use the term misopedy to refer to the denigration and subordination of children and childhood. ${ }^{2}$ Misopedy is an ancient form of social and political hierarchy. Despite the fact that 'European xenophobic traditions such as anti-Semitism, Islamophobia, or Negrophobia are considerably older than race $^{\prime}{ }^{3}$ misopedy appears to be older still. The idea of a telos of progress from animal child to human adult is both a historical and conceptual antecedent of the idea of European civilization, prefiguring its stories about maturation and progress from cultural ignorance to enlightenment.

While analyses of how race and gender relate to coloniality provide valuable insights, ${ }^{4}$ contemporary processes of settler colonial dispossession and assimilation can only be fully understood through the lens of misopedy. Just as the adult was conceptualized in contradistinction to the child as an ontological 'other', the 'Indian' came to be situated as the other of the European. ${ }^{5}$ The eighteenth-century historian, Frederich von Schiller, provides a classic illustration of how Indigenous peoples were constructed as savage 'Indians' through their classification as children:

The discoveries which our European seafarers have made in distant oceans and on remote shores afford us a spectacle which is as instructive as it is entertaining. They show us societies arrayed around us at various levels of development, as an adult might be surrounded by children of different ages, reminded by their example of what he himself once was and whence he started. A wise hand seems to have preserved these savage tribes until such time as we have progressed sufficiently in our own civilization to make useful application of this discovery, and from this mirror to recover the lost beginning of our race. But how embarrassing and dismal is the picture of our own childhood presented in these peoples! ${ }^{6}$

In his nineteenth-century commentary on Chief Pontiac, Francis Parkman (whom Roy Harvey Pearce called 'the prime historian of the victory of civilization over savagism') provides another instructive passage on the 'Indian' constructed as child:

Pontiac was a thorough savage, and in him stand forth, in strongest light and shadow, the native faults and virtues of the Indian race. All children, says Sir Walter Scott, are naturally liars; and truth and honor are developments of later education. ${ }^{7}$

Even here, in the late eighteenth century, the construction of the native is not essentially a racial project. In the same way that Schiller depicted native 'races' as peoples emerging from civilizational childhood, Parkman is also clear that the virtues and vices of the native are found in all feral children of civilization, including white European ancestors, irrespective of race:

Barbarism is to civilization what childhood is to maturity; and all savages, whatever may be their country, their color, or their lineage, are prone to treachery and deceit. The barbarous ancestors of our own frank and manly race are no less obnoxious to the charge than those of the cat-like Bengalee; for in this childhood of society brave men and cowards are treacherous alike. ${ }^{8}$

The colonial denial of full humanity usually takes two forms. The first is totalizing and involves the depiction of peoples as non-human animals, insects, or vermin. ${ }^{9} \mathrm{We}$ find this discourse most ominously deployed in the context of physical genocide. The second functions much differently for it not only justifies the use of coercion and violence but frames it as an obligatory means of inducing maturity - of motivating 
feral or premodern peoples along the natural telos of humanity towards the fulfilment of a normative ideal of progress. The result is a form of cultural genocide. In the context of contemporary settler colonialism, it is this second form of denial that demands greater analysis.

Re-imagining Indigenous peoples as 'Indians' was crucial in legitimizing colonial claims to territorial sovereignty. ${ }^{10}$ The dual colonial mandates of dispossession and pacification were advanced by modelling Indigenous peoples - legally and politically - according to the only existing class of people in Western thought for whom there existed a moral obligation to provide assistance but for whom political claims were impossible: children. Through this specific classification, a number of colonial functions that could not be accomplished by racial, ethnic, linguistic, or geographical distinctions alone were advanced. Colonial actors were fundamentally concerned with disqualifying Indigenous peoples as political agents with sufficient intelligence or reason to form political communities with legitimate claims to nationhood, land, and sovereignty. As Patrick Wolfe observes: 'Indigenous North Americans were not killed, driven away, romanticized, assimilated, fenced in, bred White, and otherwise eliminated as the original owners of the land but as Indians. ${ }^{\prime 1}$ Securing resource extraction, trade, commerce, and governance - European benchmarks of cultural progress - proved nearly impossible without pacification of Indigenous territories, a goal best served by the coerced education and assimilation of the 'Indian' in Christian faith and/or Enlightenment reason. The hierarchy and violence embodied in the forced removal and education was justified according to the doctrine of civilizational progress out of childhood. ${ }^{12}$

\section{Who is the child?}

In most Western traditions, 'childhood' is a social category constructed around the physiological and cognitive differences that characterize the early life of human beings. The category of child is comprised of a set of ideas and imaginaries that organize how older people think and act in relation to young people. ${ }^{13}$ The differences between young and older (like the differences between black and white, male and female) are socially (re)constructed to form a binary opposition between 'child' and 'adult'. Specifically, the child is characterized by the absence of distinctly human agency, a 'childhood animality' standing in contradistinction to the (ideally) autonomous rationally motivated action of the fully human adult. ${ }^{14}$ Children are not simply human beings with different ways of interacting with the world and others, they are a lesser, deficient, or otherwise incomplete form of human being.

This formulation has remained constant from its origins in ancient Greece to today. The renowned French historian of childhood, Philippe Ariès, argued that the Western conception of childhood did not emerge until roughly the sixteenth century. For Ariès, the idea that childhood is a distinct phase of life, along with the emergence of new institutions designed to protect and educate children, were shifts associated with the rise of modernity. ${ }^{15}$ Ariès asserted that prior to the modern era, young people were viewed as miniature adults who were treated with relative indifference, evidenced in part by the changing depiction of children in European art from undersized adults to schoolchildren. Ariès' critics have correctly argued that there has always been recognition of the unique character of childhood in contrast to adulthood. ${ }^{16}$ Despite shifting conceptions of childhood 
inferiority, the child has been consistently understood as a subordinate and only partially human being who must be guided into maturity through education. ${ }^{17}$ What distinguishes the modern conception of the child, then, is the shift out of a medieval idea of progress through education in faith to the Enlightenment ideal of perfectibility through education in reason. ${ }^{18}$ From its earliest formulations adulthood is viewed as an inherently political existence understood in opposition to a child's non-political or pre-political way of being. ${ }^{19}$

\section{Civilizational homology}

Before I present the historical development of coloniality, I would like to clarify why the identification of Indigenous cultures with children is not just a paternalistic analogy or just one among many contingent tropes of colonial superiority. The relationship is not simply rhetorical, as we see when Philip Deloria writes that child and the native are 'paired rhetorically as natural, simple, naive, preliterate, and devoid of self-consciousness'. ${ }^{20}$ Rather, the degraded figure of the child provides the internal structure and logic of the colonial conception of the 'Indian'. The rhetorical device of analogy works by highlighting similarities that are coincidental rather than inherent. Analogy, like metaphor, does not entreat us to approach the objects of association as essentially the same simply because they might appear the same. In this sense, analogy is distinct from homology. Homology pertains to shared processes or structures which are linked and can be treated as identical despite other differences. The skeletal structure of the human hand, for instance, is not analogous to the skeletal structure of a whale's flipper. Rather, they are homologous because they share a common structure and a shared evolutionary origin despite appearing different.

Ideological and philosophical processes can be structured homologously as well. When writers invoke the image of organic biological growth or geologic change to illustrate changes in individual and civilizational development they are deploying an analogy. Metaphors referring to the growth of plants do not invoke the same internal logic of progress through education as the homology, nor the moral obligation to encourage progress through the disciplining of children and, by extension, of Indigenous cultures. Within the homology, children and Indigenous cultures progress from animal-human to fully human through the identical mechanism of education in either faith or reason. ${ }^{21}$ In the Western teleological account of reason, the mechanisms of development from, on the one hand, child to adult, and, on the other hand, from premodern to modern, are fully homologous. This is why, in the settler colonial framework, children and Indigenous cultures are understood as the beneficiaries of violence: it is a moral requirement that those in a superior and authoritative position oversee the transition of an inferior and subordinate state of being to a mature being. ${ }^{22}$ Educational discipline is unavoidable because mere physiological development, the root of civilizational metaphor, does not guarantee intellectual and civilizational progress. Thus, European powers have a responsibility to educate Indigenous societies, a function of the civilizing mandate of misopedy according to which adults are morally obligated to raise children out of the darkness of sin and ignorance.

The origins of the homology pre-date oral and written records, but it might help to consider some of the reasons why children have been subject to such subordination in the first place. One strong possibility is that an intellectually satisfying justification was 
required to legitimize the various domestic economies, affluence, and privileges that came as a result of child labour. From at least the classical period up to the mid-nineteenth century, children were used as free labour (often as expendable slaves) whose productivity turned out to be central to the historical emergence of various agricultural and industrial revolutions, including the rise of industrial capitalism. ${ }^{23}$ Adults were exploited and enslaved as well, but the speed and intensity of economic growth in Europe could not have be secured by adult labour alone. In nineteenth-century Britain, for example, children constituted up to $50 \%$ of the work force in many industries. ${ }^{24}$ The material surpluses and wealth produced through the forced labour of children have transformed Western society numerous times. During these transformative epochs, many adults found themselves released from the demands of subsistence labour as well as the care of children. The wealth and leisure time established in part by child labour in ancient Greece as in Modern Europe was devoted to the cultivation of religion, art, philosophy, politics, and science. The subordination of an entire class of peoples according on their cognitive immaturity was essential to the emergence of industrial capitalist modernity. ${ }^{25}$ Not surprisingly, the principal beneficiaries of child exclusion and exploitation were responsible for devising self-serving justifications for their new position and pastimes, ad hoc rationalizations of adult privilege based on the argument that philosophers and politicians were not bound by necessity precisely because they were not the children who served and laboured under them. While we cannot say with any certainty how children came to be portrayed as the antithesis of the fully human political agent, it seems reasonable to assume that these representations were rooted in the conditions under which adults benefitted from the child's subjugation. With this in mind, let us turn to a historical discussion of how the civilizational homology led to the dispossession and assimilation of Indigenous peoples through their classification as children.

Although the Western idea of civilizational progress would take many forms over time (e.g. Christian, cultural, national, and scientific), each instantiation features the same defining central logic: human beings, as individuals and as a species, progress out of a bestial state into a fully human state through education. ${ }^{26}$ This central logic embodies a veneration of logos, language and reason, as the definitively human form of relating to the world and others, always and explicitly understood in contradistinction to the animalian or feral child's rational deficiency. ${ }^{27}$ Classified as the orphans of civilization, native peoples were conceptually and legally precluded from making claims to land. In virtually all European legal codes, as in British common law, those born out of wedlock and therefore without parentage 'can inherit nothing, being looked upon as the son of nobody; and sometimes called filius nullius'. ${ }^{28}$ The colonial categorization of natives as the children of no one and inheritors of nothing is mirrored in the categorization of the land as having no inherent claim upon it, as terra nullius. Indigenous peoples were situated as feral humans (homo ferus) and defined legally as wards of the paternalistic sovereign whose executive in the United States, the Great White Father, stood as the representative of settler democracy and civilization. ${ }^{29}$

Thus, premodern societies are not simply like children - they are not merely analogous for they act according to the same crude cognitive processes or patterns. ${ }^{30}$ Though I will be dealing mainly with the structure of settler colonialism in the New World, there are strong parallels elsewhere. As post-colonial scholar Uday Singh Mehta observes, almost all non-Western peoples have 'from the outset been coded as a child'. ${ }^{31}$ Childhood reflects 
'the fixed point underlying the various imperial imperatives of education, forms of governance, and the alignment with progress'. ${ }^{32}$ As Edward Said has noted, in the global colonial imagination the 'Oriental is irrational, depraved (fallen), childlike, "different".' Likewise, the 'Arabs are made to rejoin the very broad designation, common to modern anthropological thought, of the childish primitive. ${ }^{33}$ The modern age is thus an age in a very literal sense. Modernity is the age that gives rise to the possibility of individual liberty, democracy, science, technology, etc.

\section{Ancient Greek and Roman coloniality}

Philosophers, playwrights, and historians in ancient Greece tended to associate labour with dependence and necessity, a degraded state of being for which the child stood as a perennial archetype. ${ }^{34}$ Physical and material dependency - vulnerability - was resented and considered indicative of inferior virtue and constitution. ${ }^{35}$ Writers from Greek antiquity lamented the miserable helplessness of infants and the absolute dependence of children. ${ }^{36}$ Throughout this historical period, most young boys and girls lived in conditions of servitude or slavery as legal and political non-persons. ${ }^{37}$ It is altogether unsurprising, then, that the Greeks employed the same word for both child and slave (pais) since servitude was considered the natural condition of those whose lack of reason rendered them incapable of organizing their own lives. ${ }^{38}$ It was Aristotle's view that slaves, women, and children are naturally excluded from political life on the grounds that they possessed deficient forms of reason and speech (logos). ${ }^{39}$ But while there was debate even among ancient thinkers concerning the validity of natural slavery for adults or the natural subordination of women, the natural slavery and subordination of children was self-evident. Unlike slavery or the subjugation of women, there is no historical record from the period suggesting that the legitimacy of excluding and dominating children was ever a question. This complete erasure suggests that misopedy was foundational to Greek political thought and practice in a way that was not even true of hierarchies rooted in slavery or gender.

The unquestionable natural subordination of the child was the backdrop against which those who were not subject to civilizing instruction were conceptualized as feral children, peoples trapped in a bestial state without language or reason. ${ }^{40}$ The identification of political agency with reasoned speech (logos) had the effect of defining politics itself in contradistinction to the child, a formulation that would prove central to Greek justifications of empire. The Greeks were fond of mocking incomprehensible speech, be it the babble of a baby or the babble of a non-Greek speaker. ${ }^{41}$ Indeed, the terms baby, babble, and barbarian derive from the same Indo-European root $b a b a$, connoting the incomprehensible speech of the infant (likewise, 'infant' from the Latin in fans, connoting 'without speech'). ${ }^{42}$ The invasion and enslavement of 'barbarian' cultures, fit only to be governed, was an extrapolation of the violence and servitude suited to the degraded figure of the child.

It is also in Roman antiquity that we find precedent for the legal and political classification of adults as children. In ancient Rome, the legal principle of paterfamilias positioned children as property of their father based on the idea that children are dependants who cannot exercise genuine agency. ${ }^{43}$ The status of child was not related to age. Even as children grew into adults they were not free until their father died or they underwent the 
onerous legal process of emancipation similar to the manumission of slaves. ${ }^{44}$ With childhood conceived as a category of dependence, irrespective of age, labour and childhood become inextricably linked irrespective of class. The adult children of wealthy citizens were no less the property of their fathers than the adult children of non-citizens. Indeed, when Roman census-takers came across parents who did not meet minimum property requirements for citizenship, the parent's children - in Latin, proles - were then listed as their contribution. The Roman term proletarius denoted the lowest class of propertyless peoples whose sole contribution was to produce children who could serve as future labourers and slaves. ${ }^{45}$ The legal status of free children shifted over time, but for much of the Roman era fathers held absolute power (potestas) over both children and slaves in the household. A father was entitled to organize the marriage and reproductive life of both his children and his slaves, or even to kill them. ${ }^{46}$ Powers over life and death (vitae necisque potestas) were legally recognized even if they were rarely exercised, especially after the Christianization of Rome in the fourth century when violence towards children was acknowledged as in a different category than violence towards slaves. Despite some legal differences between free children and enslaved children, violence against free children was still considered a necessary feature of education, stern even if not excessive, irrespective of class. ${ }^{47}$

Well over 1000 years before New World contact with Indigenous peoples, Western political thought and practice were predicated on the political exclusion and violent education of both children and adults who were categorized as children. And although empire came to be justified with reference to the defective reason of non-Greek 'barbarians' who, like children, were naturally servile, a conception of linear civilizational progress had not yet emerged.

\section{Medieval Christianity coloniality}

New classes of scholars who stood as beneficiaries of misopedy vociferously championed economic and political life defined in opposition to children, along with their use as labourers. To be a scholar was, in a literal sense, to have free time to deliberate (from the Greek skhole), for it was in the leisure time afforded in part by the labour of children that men could study, deliberate, and cultivate their newly realized and definitively human form of freedom and agency. In the medieval period, scholastic practice was associated with religious study of the Bible and its commentators. Soon after the fourth-century monk Pelagius' argument that children were not born with 'original sin' was declared a heresy most religious scholars proclaimed that the stain of sin incurred by Adam and Eve in the childhood of mankind is recapitulated in every child born thereafter. Salvation is dependent, therefore, on a life given over to the word of God (Logos) and it is only through education in faith that mankind progresses spiritually from a state of worldly sin towards heavenly grace.

Medieval social and political orders remained to a large extent an outgrowth of the Roman legal doctrine of paterfamilias, which early Christian thinkers reconceived as a theological principle. The Christian order came to depicted as a human family bound in a divinely ordained hierarchical order, a great chain of being with the King as representative of God standing as father to his earthly family. Building off the Greek and Roman vilification of bestial childhood, children were situated at the lowest levels of creation, below adult 
human beings and just above the animals. Civilizational discourses began to emerge as Christian thinkers introduced the idea that humanity itself advances along a linear historical trajectory. In the fourth century, Augustine became one of the first thinkers to reject the cyclical Hellenistic view of history - the view that that there is nothing new under the sun and time is a recursive succession of growth and deterioration. ${ }^{48}$ Augustine's key innovation was to understand the birth of Jesus as a singular, unprecedented, unrepeatable event, and the final days of judgement as the ultimate terminus of Man's spiritual progress. ${ }^{49}$

Augustine's vision of progress did not take place on earth, however. In the fall of Rome, Augustine saw proof that civilizations on earth were destined to go through natural stages of birth, flowering, and decay. Our worldly existence was to be contrasted with our progress in faith towards the City of God as a final spiritual destination. ${ }^{50}$ The universal condition of original sin entails that mankind cannot do it alone. God's providence is required since humanity exists in a state of shameful childhood precisely because original sin is embodied in every generation born to earth. The Greco-Roman traditions of discipline and education were now in the service of the child's deliverance from degrading worldliness (original sin) into the salvation of spiritual maturity. ${ }^{51}$ J.B. Bury, a historian of the idea of progress, observed that in the Augustinian spiritual scheme a doctrine of historical progress was not conceivable: 'as long as the human species endures on earth, every child will be born naturally evil and worthy of punishment, a moral advance of humanity to perfection is plainly impossible'. ${ }^{52}$ As one writer summarized the medieval Christian view of children: 'A child was not believed to be truly human simply by birthright; he was a creature in search of humanity - unpredictable, capable of animal indolence, selfishness, and savagery. ${ }^{53}$ Looking into the past, however, Augustine optimistically suggests that the development of mankind has been inextricably linked to the progression out of childhood towards a devout maturity in faith. ${ }^{54}$

\section{Contact}

It was in the context of the medieval history of child brutality and enslavement that first contact was made with Indigenous peoples in the New World. Within decades, native peoples were subject to violent dispossession and enslavement. In 1532, the Catholic philosopher Francisco de Vitoria offered a defence of Indigenous peoples, arguing that they should be free from slavery and permitted to own property and trade that property with Spain. Vitoria was also clear, however, that Spain legitimately asserts sovereignty over native lands. Indigenous peoples, while 'not wholly unintelligent', are nevertheless 'little short of that condition, and so are unfit to found or administer a lawful State up to the standard required by human and civil claims..$^{55}$ Specifically, the step of imposing colonial order is necessary when Indigenous peoples are found to lack adult capacities for reason: 'sovereigns would be bound to take it, just as if the natives were infants'. ${ }^{56}$ In keeping with the categorization of adults as children, which dates back to at least ancient Rome, native adults were in Vitoria's estimation legitimately seen as children if they exhibit the same deficiency of reason.

Vitoria's very early categorization of Indigenous peoples as children is linked to his defence of a natural right of European powers to travel, trade, and occupy terra nullius. He formulates the law of nations (ius gentium) such that Indigenous peoples are prohibited from rejecting trade and commerce with Spain, and Spain is under no obligation to cease 
exploration, settlement, and trade. Indeed, since so many native peoples had been successfully converted to Christianity, Vitoria suggests that it would be 'neither expedient nor lawful for our sovereign to wash his hands entirely of the administration of the lands in question'. ${ }^{57}$ In Vitoria's influential view, Indigenous leadership is bound by the law of nations to accept trade with Spain, for whom 'if it be necessary, in order to preserve their right, that they should go to war, they may lawfully do so'. ${ }^{58}$ By invoking the homology of individual and civilizational progress through education of the sinful child in faith towards salvation, Vitoria disqualifies native peoples and their claims to nationhood on the grounds that they have proven incapable of supporting the 'human and civil claims' required to uphold property rights and markets. Misopedy, then, is the pretence upon which Vitoria naturalizes Spain's assertion of sovereignty 'as if the natives were infants'. In less than a century following first contact 'the image of the Indian as a natural slave was replaced by that of the Indian as child'. ${ }^{59}$ In 1537, Pope Paul III issued a papal bull, Sublimis Deus, declaring that Indigenous peoples of the Americans could not be enslaved because they were in fact fully human. The decree also stipulated that Indigenous peoples could not be disposed of their property, which did nothing to restore territories back to sovereign Indigenous nations.

In 1547, Juan Ginés de Sepúlveda published 'On the Reasons for the Just War among the Indians' wherein he repeated the Greek and Medieval homology which extrapolated the legitimacy of colonial rule from the idea that 'the rational part of the soul rules and directs the irrational part, which submits and obeys':

The man rules over the woman, the adult over the child, the father over his children. That is to say, the most powerful and most perfect rule over the weakest and most imperfect. This same relationship exists among men, there being some who by nature are masters and others who by nature are slaves. Those who surpass the rest in prudence and intelligence, although not in physical strength, are by nature the masters. ${ }^{60}$

In 1550, reports of brutal violence and enslavement of native peoples reached the King of Spain, Charles V, who then initiated debate involving Catholic thinkers as to whether Indigenous peoples were natural slaves or fully human. Sepúlveda's opposition in what came to be known as the Valladolid debate was Bartolomé de las Casas, who largely echoed Vitoria's defence of Indigenous peoples. Las Casas argued that Indigenous nations often exhibited spiritual and political maturity at least on par with Europe's ancient civilizations. Although a group of 'Indians' may still qualify as barbarian in the formal sense that they might be illiterate, this was no less true of the English nation at one point in history. Las Casas contends that the absence of reason or the degeneration of reason can be found in both European and 'Indian' societies and was therefore 'accidental and not natural'.61

Far from rejecting the civilizational homology deployed by Sepúlveda, Las Casas affirmed it so as to argue that some Indigenous peoples did in fact (or, through education, could potentially) qualify as mature societies. Such a defence stands as the pre-cursor of Lockean idea that there is nothing inherently defective about the reasoning capacities of the 'Indian', but rather, the absence of reason is an accident of history that can and must be addressed through education. Subsequent justifications of settler colonial expansion would also echo Vitoria's assertion that Spain had an obligation to establish its sovereignty and administer over lands in order to cultivate the legal conditions of trade and 
commerce. By the late sixteenth century, Spain formally shifted from a discourse of legitimate conquest to 'pacification' of land and Indigenous peoples, though in practice the brutal treatment of the 'Indian' changed very little.

\section{Enlightenment and romantic coloniality}

In the centuries that followed, the traditional hierarchies constituting medieval social and political order were slowly eroded by the rise of Protestantism, radical interpretations of the Christian ideal of equality under God, the successes of scientific inquiry and the amassing of private fortunes. Education in faith, once posited as the process of Man's progress and the hallmark of European maturity was increasingly associated with childish superstition. Enlightenment thinkers declared that the light of human reason was poised to vanquish the darkness of childish faith as the proper foundation of political order and the engine of civilization progress. A core idea of the emerging humanism was that intellectual improvement as opposed to spiritual improvement was the main driver of historical progress. As a result, education in faith was gradually replaced with a more secular, humanistic, and science-based curriculum.

The self-understanding of settler colonial powers would shift during the era of Enlightenment, most notably in its break with the Roman doctrine of paterfamilias and its Christian manifestation in the divine right of Kings. Still, there were some notable final attempts to salvage the monarchical vision of sovereignty. In 1680, Robert Filmer would produce one of the last great defences of the medieval homology between adulthood and civilization, asserting that a King's right to rule his domain and subjects was a direct expression of the father's right to rule over the household and child (a premise with which, he Filmer puzzled, no one seemed to have a problem):

I see not then how the children of Adam, or of any man else, can be free from subjection to their parents. And this subjection of children being the fountain of all regal authority, by the ordination of God himself. ${ }^{62}$

In response, a distinction was devised in political thought between parental authority and political authority. In the work of social contract theorists, the legitimacy of political authority was seen as contingent on reasoned consent. ${ }^{63}$ In an ingenious theoretical move, Thomas Hobbes argued that the violence of political disorder which results from fractured sovereignty, the infamous 'state of nature', is the basis of our reasoned consent to absolute sovereignty. ${ }^{64}$ Likewise with respect to parental authority, reasoned consent may be implied since every family is always 'a little Monarchy'. ${ }^{65}$ In the work of Hobbes, not only does consent establish the legitimacy of political sovereignty, consent can be presumed rather than actual.

It is in the work of John Locke that we find the most lasting and influential shift in the civilizational homology between child and native. Locke rejected both Hobbes' and Filmer's defences of absolute sovereignty, arguing in a move reminiscent of Vitoria that political rule exists to preserve the property rights and commercial institutions already established by civil society. Citizens consent only insofar as political rule is governed by reason and they may also reform it whenever it fails to protect civil society. A complication arose, however, as Locke's defence of the reasoned consent seemed to imply that parents did not have a right to govern children who had not (or could not) consent. Locke follows 
Hobbes, arguing that children are born free and rational insofar as they have the potential to exercise capacities for reason. ${ }^{66}$ Whereas the principle of paterfamilias designated children as the disposable property of parents even into adulthood (as subjects are to Kings), Locke argued that children are God's property. ${ }^{67}$ Moreover, he claimed that parental rule over children was temporary, that parents had a natural duty to educate children in the use of reason and parental authority ended once children became reasoning adults. Locke's children are not respected on their own terms but only insofar as they are becoming something other than children. Rights are extended not to children qua children, but to potential adults who exist only temporarily in the imperfect state of childhood. ${ }^{68}$

This new enlightened approach preserved the developmental homology of earlier epochs. Locke's work reflects a critical shift from classical misopedy, according to which the bestial child is property of the parent, to the Enlightenment misopedy wherein the bestial child is given the status of a ward under the guardianship and protection of the parent. Locke does not appear to attribute naturally defective reason to Indigenous peoples. Rather, 'Indians' were depicted as no more or less potentially rational than Europeans. ${ }^{69}$ As children of civilization, Indigenous peoples are not inherently inferior, but rather, temporarily inferior. And herein we can identify the central logic of modern colonial capitalism. Not unlike Vitoria, Locke's concern was to show that God bestowed mankind with the potential for reason and that he granted the world 'to the Industrious and Rational'. ${ }^{70}$ As long there was enough land for everyone, no person is entitled to object to or interfere with the property and industry of another. No doubt, Locke's deep commercial interests in European colonies also informed his view that Indigenous peoples who objected to colonial dispossession were intentionally situating themselves on the wrong side of the political/childhood binary. In most cases, however, the solution to Indigenous resistance was a more robust commitment to education. Colonial political thought in the seventeenth century, as exemplified in the work of Locke, couched the homology of progress from bestial child to rational adult in a more secular terms of consent and education. The link between private property, commerce, political agency, and salvation that we find in Christian thinkers like Vitoria is gradually associated with education in reason. The conceptual and institutional hallmarks of modernity take form in the context of the colonial categorization of Indigenous peoples as feral children of the Enlightenment.

The Enlightenment had its critics, of course, and given the centrality of childhood to European thought many of these critics sought to reconceptualizing the figure of the child. While it appears on the surface that a sense of dignity was being associated with childhood itself, the figure of the child was not removed from its conceptualization as the tragic antithesis of the emerging modern condition. In general, childhood animality became the object of nostalgia and fetishization rather than overt disdain: 'Children's essential animality has sometimes been viewed as problematic; at other times the animal nature of children has been idealized. The equation of child with animal remains. $^{171}$ Resisting what they considered a stifling culture of rationalism and a political fixation on a utopian political future based on reason, Romantic writers valorized the child's free, spontaneous and creative way of being as indicative of humanity's paradise lost. The inherent superiority of mature modes of modern freedom and agency were not fundamentally challenged. Modernity is characterized by the loss of childhood innocence, natural freedom, and connection to nature, but the loss is inevitable and indeed necessary for moral progress towards the political freedom realized in the constitution 
of civil and political society. The romanticized child is thus the centre of a tragic story of lost human authenticity and our alienation from the world. ${ }^{72}$

These themes were most famously explored in the work of J.J. Rousseau. In Discourse on the Origins of Inequality, for example, Rousseau claims that children and parents would, in the state of nature, have no relationship of mutual responsibility. ${ }^{73}$ Accordingly, we learn in The Social Contract that despite its flaws, modern society is essential for moral improvement and the highest forms of human freedom and sociality. ${ }^{74}$ Likewise, Rousseau's celebrated work on children, Emile, was not intended to be an education manual but rather a lament on the impossibility of raising children to be both free and functional within modern society. ${ }^{75}$ In civilizational terms, Man's original freedom - his childhood - must be sacrificed in order to pursue education. The child's courageous and impulsive state of playful being is simply incongruent with what bourgeois artists and intellectuals saw as constraining yet inevitable strictures of modern civilization. ${ }^{76}$ If a child somehow goes without education they are left in a feral or natural state of being that is identical in many ways to that of the 'Indian'. Sankar Muthu observes that Rousseau at times 'manages to equate savages (understood as the earliest purely natural individuals of his conjectural history), the "Savage Nations" of the New World, and feral children (such as the "little savage of Hanover") as "natural creatures"'. ${ }^{77}$

By the eighteenth century, romantic philosophical and literary depictions of childhood were reflected in tropes of native peoples, epitomized in the myth of the 'noble savage'. In their classification as children, following the social contract formulation, the consent of the native ward was always regarded as form of hypothetical or implied consent to the sovereign understood as parent or guardian. Unless the native had demonstrably matured through education, as evidenced by their industriousness and enthusiastic embrace of systems of private property, trade, and commerce, the explicit consent of native peoples was not required. At best, the sovereign as guardian had a self-imposed duty to consult with underdeveloped native communities and hold their wealth in trust, though in the absence of consultation the sovereign was nevertheless obliged to author decisions that were in the best interests of the native (again, according to the sovereign). Any assertion of jurisdiction over land on the part of the 'Indian' was interpreted as a failure of colonial education, a regression into childhood, and an affront to standards of civilized governance.

\section{Modernity coloniality}

The contemporary construction of native peoples as feral children has not changed much from its articulation by the social contract theorists. Since then, however, the settler colonial homology of civilizational progress has accrued a veneer of academic and scientific legitimacy that bears mention. During the late eighteenth and nineteenth centuries, a stages view of progress coalesced in the philosophical work of Kant, Hegel, Mill, and Comte that explicitly premised historical, biological, and sociological understandings of cultural evolution on the development of the child. In his formative essay, 'An Answer to the Question: What Is Enlightenment?', for example, Kant argues the Enlightenment is marked by 'man's release from his self incurred immaturity'. ${ }^{78}$ The terms in which he defines immaturity are telling: 'the inability to use one's own understanding without the guidance of another'. ${ }^{79}$ Kant's notion of immaturity preserves virtually unaltered the 
political/childhood binary born in Greek and Roman antiquity and it is central to his vision, and subsequent visions, of civilizational progress. The German word translated here as immaturity (sometimes as 'tutelage') is unmündikeit, which has as its root mund, or mouth, and connotes the ability to speak for oneself. ${ }^{80}$ While man exists in a state of immaturity - without speech - we are merely 'passive citizens'. ${ }^{81}$

Kant and his contemporaries are often criticized for espousing racist positions at the same time as they celebrate the timeless and universal nature of human rights. The issue here is the timelessness and universality of the process of maturation. The medieval homology heavily informs Kant's view that 'children ought to be educated, not for the present, but for a possibly improved condition of man in the future; that is, in a manner which is adapted to the idea of humanity and the whole destiny of man'. ${ }^{82}$ Independence must be learned, according to Kant, lest one end up like the Indigenous peoples of what is now Tahiti, 'who remain children all their lives'. ${ }^{83}$ He argued that the absence of a civil state indicates a lack of, or rejection of, reason and a threat to civilized people which justifies pre-emptive 'hostile action'. ${ }^{84}$ Like Vitoria, he sanctions violence against Indigenous peoples who, as 'immature children', violate the dictates of reason, as manifest in their rejection of private property and liberal rights. ${ }^{85}$ The identical homology is carried through in the work of John Stuart Mill, who wrote in On Liberty and elsewhere that Indigenous societies, which are to be considered children, have no rights to bodily integrity or freedom from violence. ${ }^{86}$ Mehta perfectly summarizes the colonial mandate expressed by Mill and others in the context of colonial India: 'India is a child for which the empire offers the prospect of legitimate and progressive parentage and toward which Britain, as a parent, is similarly obligated and competent. ${ }^{87}$

In the hands of Hegel, the idea that shifts in political organization signal the historical progress of reason reached unprecedented heights of philosophical abstraction. For Hegel, consciousness (Mind or Spirit) is a rational force progressing from its childhood through historical stages towards maturity. ${ }^{88}$ This dialectical passage through stages is a story of maturation and growth, which Hegel believes positions Europe, and specifically modern Germany, at the apex of historical progress. ${ }^{89}$ The individual and the whole are inextricably linked in the progress of Spirit. Indeed, the potential maturity of adults is in part restricted by the maturity of the society into which they are born. ${ }^{90}$ Reason progresses by building on the past and bootstrapping philosophical self-understanding through generations, which is an auspicious circumstance for the children of Europe who inherited centuries of Western civilization; their deliverance from savage state is virtually guaranteed as a result of being born into societies representing the historical vanguard of human progress.

The generations of intellectuals that followed Hegel were even more explicit about the structural relationship between civilizational and individual progress. In the mid-nineteenth century, Auguste Comte, the self-proclaimed father of sociology, argued that societies progress through three main stages of intellectual maturity: theological, metaphysical, and positive. ${ }^{91}$ Comte is careful to clarify that there is no mere metaphor at work in the suggestion that the progress of societies mirrors the advancement out of a state of childhood. To have a theological or metaphysical worldview is precisely what it means to be a child. Comte's 'stages' theory of human progress is important insofar as it served as the template for scientific theories of natural progress. With the publishing of Charles Darwin's Origin of the Species in 1859, the ideas of natural selection and 
evolutionary change began to shift intellectual discourse. Europe already understood itself according to an increasingly secular view of moral and political progress (in which Europe was the obvious vanguard). Darwin was familiar with Comte's philosophy, and the emerging scientific vision of biological adaptation provided an even firmer empirical foundation for doctrines of progress.

Within the burgeoning social scientific disciplines, childhood and child societies would be fixed as a stage of amorphous, irrational, savage, and even criminal state of being. ${ }^{92}$ In sciences of the mind, figures such as Sigmund Freud, Jean Piaget, Erik Erikson, and Lawrence Kohlberg proposed that children move through stages from self-centred animal instinct and desires towards abstract reasoning. Piaget advanced what he termed a 'genetic epistemology' according to which childhood before the age of seven was characterized by animism, or the belief that inanimate objects possessed a kind of agency. ${ }^{93}$ The view that Indigenous peoples were equivalent to European children around the age of seven was common. ${ }^{94}$ In 1979, the anthropologist C.R. Hallpike applied Piaget's developmental stages theory directly to Indigenous peoples, arguing, as one reviewer put it, 'that the collective representations of illiterate, unschooled, rural peoples are expressions of preoperational thought processes characteristic of two- to seven-year-old Western children, as described by Piaget'. ${ }^{95}$ The child is the cipher of the primitive, to the extent that our understanding of the savage can be discerned directly through the study of children. To that end, Freud sets out in his book Totem and Taboo 'to deduce the original meaning of totemism from the vestiges of it remaining in childhood - from the hints of it which emerge in the course of the growth of our own children'. ${ }^{96}$

Modern colonial thinkers inherited the conceptual legacy of misopedy. Early New World politicians, missionaries, and scientists, fought for exclusion from the political domain and education of the savage child embodied in the 'Indian'. The first Secretary of the Smithsonian Institution, scientist Joseph Henry, claimed that the art of Indigenous peoples demonstrated that 'the savage is but a child in intellectual development'. ${ }^{97}$ Educators like Myron Eells agreed. He wrote in an Annual Report of the Board of Indian Commissioners in the United States that 'in education, morals, food, houses, general civilization, and Christianity, he is a child. As a child he needs a home and a school'.$^{98}$ Likewise, in a debate in the Canadian House of Commons over a bill that would enfranchise Indigenous peoples, Minister J.F. Lister laid bare the structure of misopedy at the heart of Canadian colonial project: 'It should be rejected because the Indians are infants in the eye of the law, and are in a state of tutelage, under the control of the Government. ${ }^{\prime 99}$

In this section, I have briefly tracked the way an ancient distinction between the animal child and the fully human adult gave rise to a homology between individual and civilizational progress. The coloniality childhood was responsible for structuring both medieval Christian and Enlightenment justifications of settler colonial dispossession. The purpose of the review was to illustrate the foundational role that the conceptualization of native peoples as 'Indian' by way of their categorization as children has played in disqualifying them as political agents capable of forming nations with legitimate claims to land. In addition, this history is essential to an understanding of how the civilizational homology established a self-imposed obligation on the part of the sovereign state as parent or guardian to educate the 'Indian'. 


\section{Conclusion: confronting the coloniality of childhood}

Exploring the coloniality of childhood at the root of Indigenous dispossession and coerced education is indispensable to the task of interpreting and addressing present day settler colonialism, especially with respect to the former British colonies that deployed the homology such as Australia, Canada, New Zealand, and the United States. Within these states, ideals of self-government, consent, and consultation have emerged as dominant guides in addressing the legacy of settler colonialism. The ideals are, as many have observed, inherently framed in terms of adaptation to colonial economic orders. Glen Coulthard explains, for example, that we inevitably find recognition and self-government predicated on Indigenous ability to participate in the market economy. ${ }^{100}$ In approaching coloniality in isolation from the conceptual origins discussed above, we may proceed disconnected from the specific mechanisms by which native peoples' claims to political and territorial sovereignty are disqualified. The standard of civilizational maturity, formulated at the outset by Vitoria according to the medieval binary opposition between child and adult, is always already framed in terms of adherence to regimes of private property and commerce.

Thus, modern settler colonialism persists in part by ensnaring Indigenous peoples in a self-defeating performance of adulthood. Native peoples are compelled to demonstrate intellectual maturity and sophistication in order to establish the possibility and therefore the necessity of their explicit consent (rather than simply implied consent) to the plans of dominant state and market actors. This posture replicates the Enlightenment notion of a scale of civilizational progress upon which the maturity of Indigenous communities is indexed to the cultivation of literacy and marketable skills. As Fanon reminds us, there are hazards in appealing to the intellect as the defining feature of humanity: 'if philosophy and intelligence are invoked to proclaim the equality of men, they have also been employed to justify the extermination of men'. ${ }^{101}$ Some individuals and communities will be less schooled and therefore less civilized than others, which has the effect of stratifying Indigenous communities, fostering competition among them, and justifying state interventions into the lives of Indigenous families. The modern call to end child labour, likewise, was not intended as a liberation of children from their status as deficient and ignorant. Rather, the call was framed as a way of rescuing children from becoming permanently ensnared in their naturally degraded condition of ignorance and servitude. This was true both for child labourers in Europe as well as for children in Indigenous communities.

As I hope to have shown, many settler colonial dynamics of dispossession cannot be fully understood when analysed through traditional lenses of race and gender since these do not interrogate the fundamental degradation of children and childhood at the root of civilizational precepts such as Manifest Destiny, terra nullius, the white man's burden and the Doctrine of Discovery. In the work of historical thinkers such as Schiller and Parkman, we see that the violence and exploitation of settler colonial institutions can proceed irrespective of race. European peoples understood and continue to understand themselves, not as inherently exceptional, but as having already undergone the violent education in faith and reason that they are now morally obliged to impose on non-European peoples. To fully comprehend the dispossession of lands, removal of children from native communities, forced schooling, the shift from religious to secular schooling, as well as the host of institutions designed to assimilate and destroy Indigenous cultures, it is necessary to recognize that the image of the native as 'Indian' is not simply a 
racial construction but an identification of native peoples with savage childhood. ${ }^{102}$ In this light, strategies for decolonization would do well to coalesce around a more fundamental challenge to the Western homology that situates children, and by extension native peoples, as the perpetual 'Other' of modernity. Challenging the coloniality of childhood may be vital to the reassertion of Indigenous nationhood and sovereignty. ${ }^{103}$

\section{Notes}

1. Robert A. Williams Jr., Savage Anxieties: The Invention of Western Civilization (New York: Palgrave MacMillan, 2012); Roy Harvey Pearce, Savagism and Civilization: A Study of the Indian and the American Mind (Berkeley: University of California Press, 1988).

2. The term misopedy is related to terms such as misogyny (antipathy towards women and femininity) and misanthropy (antipathy towards human beings and sociality). In the late nineteenth century, psychologists coined the clinical term misopedia, but neither the term nor recognition of antipathy towards childhood gained traction in that era. For a modern example of its use, however, see Paul Stewart, Sex and Aesthetics in Samuel Beckett's Work (New York: Palgrave MacMillan, 2011). Recently, Elisabeth Young-Bruehl has used the term childism. See Elisabeth Young-Bruehl, Childism: Confronting Prejudice Against Children (New Haven, CT: Yale University Press, 2012), 4-5. The term childism was coined in Chester Pierce and Gail Allen, 'Childism', Psychiatric Annals 5 (1975): 266-70. Unfortunately, the term has been used confusingly to denote both the affirmation of childhood dignity as well as its denial. To avoid this confusion, I use the term misopedy to denote a non-clinical sense of antipathy towards children and childhood.

3. Patrick Wolfe, 'Settler Colonialism and the Elimination of the Native', Journal of Genocide and Research 8, no. 4 (2006): 387-409, 387.

4. See Daiva K. Stasiulis and Nira Yuval-Davis, eds., Unsettling Settler Societies: Articulations of Gender, Race, Ethnicity and Class (London: Sage, 1995); see also Scott Lauria Morgensen, 'Theorising Gender, Sexuality and Settler Colonialism: An Introduction', Settler Colonial Studies 2, no. 2 (2012): 2-22.

5. Pia Christensen, 'Children as the Cultural Other: The Discovery of Children in the Social Cultural Sciences', Kea Zeitschrift fir Kulturwissenschaflen 6 (1994): 1-16.

6. In Friedrich von Schiller, 'The Nature and Value of Universal History: An Inaugural Lecture', History and Theory 11, no. 3 (1972 [1789]): 321-34, 325.

7. Quoted in Pearce, Savagism and Civilization, 166.

8. Ibid.

9. See David Livingstone Smith, Less than Human: Why We Demean, Enslave, and Exterminate Others (New York: St. Martin's Press, 2011), 152.

10. James Tully, Public Philosophy in a New Key, vol. 2 (Cambridge: Cambridge University Press, 2008), chap. 5.

11. Wolfe, 'Settler Colonialism', 388.

12. Anne McClintock, Imperial Leather: Race, Gender, and Sexuality in the Colonial Contest (New York: Routledge, 1995), 45.

13. On the Western social construction of childhood, see Allison Jenks, Chris Jenks, and Alan Prout, Theorizing Childhood (Cambridge, UK: Polity Press, 1998); Hugh Cunningham, The Children of the Poor: Representations of Childhood since the Seventeenth Century (New York: Blackwell), 1991; Chris Jenks, Childhood (New York: Routledge, 1996); Allison James and Adrian James, Construction Childhood: Theory, Policy and Social Practice (New York: Palgrave Macmillan, 2004); and Barry Mayall, Towards Sociology of Childhood: Thinking from Children's Lives (Philadelphia: Open University Press, 2002).

14. Gail F. Melson, Why the Wild Things Are: Animals in the Lives of Children (Cambridge, MA: Harvard University Press, 2001), 36.

15. Philippe Ariès, Centuries of Childhood: A Social History of Family Life, trans. Robert Baldick (New York: Random House, 1962). 
16. David Archand, Children: Rights and Childhood (New York: Routledge, 1993), 19.

17. Ibid., 22.

18. For a contemporary critique of the idea of progress, see John Gray, The Silence of Animals: On Progress and Other Modern Myths (New York: Farrar, Straus and Giroux, 2013).

19. See Gene Myers, The Significance of Children and Animals: Social Development and Our Connections to Other Species (West Lafayette, IN: Purdue University Press, 2007), chap. 2; Hugh Cunningham, Children and Childhood in Western Society since 1500 (New York: Routledge, 2005), 43, 58; Peter N. Stearns, 'Childhood Emotions in Modern Western History', in Routledge History of Childhood in the Western World, ed. Paula S. Fass (New York: Routledge, 2013), 158-73, 160; Colin Heywood, A History of Childhood: Children and Childhood in the West from Medieval to Modern Times (Malden, MA: Blackwell, 2001), 116; Christina L.H. Traina, 'A Person in the Making: Thomas Aquinas on Children and Childhood', in The Child in Christian Thought, ed. Marcia J. Bunge (Grand Rapids, MI: Wm. B. Eerdmans, 2001), 103-33, 126; and Matthew Cole and Kate Stewart, Our Children and Other Animals: The Cultural Construction of Human-Animal Relations in Childhood (Burlington, VT: Ashgate Press, 2014).

20. Philip J. Deloria, Playing Indian (New Haven, CT: Yale University Press, 1998), 106.

21. On the use of metaphors in interpreting history, see Robert Nisbet, Metaphor and History: The Western Idea of Social Development (New Brunswick, NJ: Transaction, 2009).

22. See Owen, Between Reason and History, 75-6. I follow Owen in holding that the concept of development is descriptive where 'the concept of progress is an evaluative or normative term' (76).

23. For discussion of the role of child labour in sustaining the Greek household, see Mark Golden, Children and Childhood in Classical Athens (Baltimore: Johns Hopkins University Press, 1990), chap. 2. For the role of child labour in sustaining Roman estates, see Christian Laes, Children in the Roman Empire: Outsiders Within (Cambridge: Cambridge University Press, 2011), chap. 5. For discussions of the modern contributions of child labour, see Peter Kirby, Child Labour in Britain, 1750-1870 (New York: Palgrave MacMillan, 2003) and Jane Humphries, Childhood and Child Labour in the British Industrial Revolution (Cambridge: Cambridge University Press, 2010).

24. Humphries, Childhood and Child Labour, 30.

25. See Jennifer Pitts, 'Empire, Progress, and the 'Savage Mind", in Colonialism and Its Legacies, ed. Jacob T. Levy and Iris Marion Young (Lanham, MD: Lexington Books, 2011), 21-52.

26. I will not be discussing the exclusion or domination of animals which clearly informs the denigration of children and childhood as bestial. For a discussion of this topic, see Sue Donaldson and Will Kymlicka, Zoopolis: A Political Theory of Animal Rights (Oxford: Oxford University Press, 2011).

27. See Robert Nisbet, History of the Idea of Progress (New Brunswick, NJ: Transaction, 2009), xii, 43-6.

28. William Blackstone, Commentaries on the Laws of England (New York: Harper and Brothers, 1852 [1765]), 458.

29. Francis Paul Prucha, The Great Father: The United States Government and the American Indians (Lincoln: University of Nebraska Press, 1984). See also Lorenzo Veracini, Settler Colonialism: A Theoretical Overview (New York: Palgrave Macmillan, 2010), 80.

30. In the words of Indian social philosopher, Ashis Nandy, following the rise of industrial capitalism in Europe, 'normal modern adulthood could no longer be conceptualized without conceptualizing its opposite, modern childhood'. Ashis Nandy, 'Reconstructing Childhood: A Critique of the Ideology of Adulthood', Alternatives X (Winter 1984-1985): 359-75, 363.

31. Uday Singh Mehta, Liberalism and Empire: $A$ Study of Nineteenth-Century British Liberal Thought (Chicago: University of Chicago Press, 1999), 14. See also Jennifer Pitts, A Turn to Empire: The Rise of Imperial Liberalism in Britain and France (Princeton, NJ: Princeton University Press, 2005), 37, 200.

32. Mehta, Liberalism and Empire, 31. The contemporary of Kant and Herder extends the homology to humanity. See John Wall, Ethics in Light of Childhood (Washington, DC: Georgetown University 
Press, 2010), 28; cf. Johann Gottfried Herder, Outlines of a Philosophy of the History of Man: Volume I, trans. T. Churchill (London: J. Johnson, 1803), vi.

33. Edward Said, Orientalism (New York: Vintage, 1979), 40, 247.

34. Golden, Children and Childhood in Classical Athens, chap. 1.

35. Aristotle, Nichomachean Ethics, 1166a17-19. See also Wall, Ethics in Light of Childhood, 39-41.

36. Lloyd deMause, ed., 'The Evolution of Childhood', in The History of Childhood (New York: Rowman \& Littlefield 1974), 1-74, 37.

37. See, for instance, Christian Laes, Children in the Roman Empire: Outsiders Within (Cambridge: Cambridge University Press, 2006), chap. 5.

38. The Latin term puer was also the term for both child and slave. See Harve E. Rawson, Talking Animals (Dictio Grex): A Primer on the History of Slavery (Bloomington, IN: Authorhouse, 2010), 25. The Old French term boi, which denoted a contemptible servant, would later refer to both male children as well as enslaved black men. Blacks in the Jim Crow era resisted by referring to one another as 'man', conferring to one another the dignity of adulthood. See W.D. Wright, Racism Matters (Westport, CT: Praeger, 1998), 47.

39. Plato, Republic, 431c; Aristotle, Politics, 1260a.

40. See Aristotle, Politics, 1254b21-24.

41. For an overview of how adults are denigrated by being called children in Western antiquity, see James M.M. Francis, Adults as Children: Images of Childhood in the Ancient World and the New Testament (New York: Peter Lang, 2006).

42. The root $b a b a$ is also etymologically related to the term Indian brave.

43. Kate Cooper, The Fall of the Roman Household (Cambridge: Cambridge University Press, 2007), 111.

44. Jan Gardner, Family and Familia in Roman Law and Life (Oxford: Oxford University Press, 1998), 79-80.

45. See Thomas Nail, The Figure of the Migrant (Redwood City, CA: Stanford University Press, 2015), 85-6.

46. George Mousourakis, Fundamentals of Roman Private Law (New York: Springer, 2012), 88-91.

47. Seneca, On the Firmness of the Wise Man, 12. See also Jonathan Edmondson, 'Slavery and the Roman Family', in The Cambridge World History of Slavery: Volume 1: The Ancient Mediterranean World, ed. Keith Bradley and Paul Cartledge (Cambridge: Cambridge University Press, 2011), 337-61, 358.

48. See Theodor E. Mommsen, 'St. Augustine and the Christian Idea of Progress: The Background of the City of God', Journal of the History of Ideas 12, no. 3 (1951): 346-74.

49. Nisbet, History of the Idea of Progress, xii.

50. Nisbet, Metaphor and History, 217. See also Wall, Ethics in Light of Childhood, 27.

51. Augustine, City of God Against the Pagans, ed. R.W. Dyson (Cambridge: Cambridge University Press, 1998), 1072-73.

52. J.B. Bury, The Idea of Progress: An Inquiry into Its Origin and Growth (New York: Macmillan, 1932), 22.

53. Steve Ozment, When Fathers Ruled: Family Life in Reformation Europe (Cambridge, MA: Harvard University Press, 1983), 138.

54. Augustine, City of God, X, 14.

55. Quoted in Robert A. Williams Jr., The American Indian in Western Legal Thought: The Discourses of Conquest (Oxford: Oxford University Press, 1990), 104.

56. Ibid.

57. Quoted in L.C. Green and Olive P. Dickason, The Law of Nations and the New World (Edmonton: University of Alberta Press, 1993), 47.

58. Ibid., 43.

59. Bianca Premo, Children of the Father King: Youth, Authority and Legal Minority in Colonial Lima (Chapel Hill: University of North Carolina Press, 2005), 32.

60. Quoted in Aaron M. Shatzman, The Old World, the New World, and the Creation of the Modern World, 1400-1650 (New York: Anthem Press, 2013), 74. 
61. Bartolomé de Las Casas, 'Apologetic History of the Indies', http://www.columbia.edu/acis/ets/ CCREAD/lascasas.htm (accessed May 17, 2016).

62. Robert Filmer, Patriarcha and Other Writings, ed. Johann P. Sommerville (Cambridge: Cambridge University Press, 2000), 7.

63. Ibid., 139.

64. Thomas Hobbes, Leviathan, ed. Richard Tuck (Cambridge: Cambridge University Press, 1996).

65. Ibid., XX.

66. John Locke, Second Treatise (Cambridge: Cambridge University Press, 2005 [1689]), §61, page 308.

67. Locke's contemporary, Samuel Pufendorf, had also rejected the idea that parental authority should include authority over life and death. Samuel Pufendorf, On the Duty of Man and Citizen, ed. James Tully (Cambridge: Cambridge University Press, 1991), 124.

68. This argument is made convincingly in Barbara Arneil, 'Becoming Versus Being: A Critical Analysis of the Child in Liberal Theory', in The Moral and Political Status of Children, ed. David Archard and Colin M. Macleod (Oxford: Oxford University Press, 2002), 70-94.

69. David Armitage, 'John Locke: Theorist of Empire?', in Empire and Modern Political Thought, ed. Sankar Muthu (Cambridge: Cambridge University Press, 2012), 84-110.

70. Locke, Second Treatise, §34, page 291.

71. Melson, Why the Wild Things Are, 35.

72. As with most adult categorizations of children, this particular fetishization of childhood innocence was also a source of neglect and, in some cases, sexual exploitation. See Larry Wolff, 'The Child in the Enlightenment: The Complications of Innocence', in The Routledge History of Childhood in the Western World, ed. Paula S. Fass (New York: Routledge, 2013), 78-100. See also Wall, Ethics in Light of Childhood, 23-4.

73. J.J. Rousseau, The Discourses and Other Early Political Writings, ed. Victor Gourevitch (Cambridge: Cambridge University Press, 1997), 157.

74. J.J. Rousseau, The Social Contract and Other Later Political Writings, ed. Victor Gourevitch (Cambridge: Cambridge University Press, 1997), 154.

75. J.J. Rousseau, Emile (London: Dover, 2013), 53.

76. Ondina E. González, 'Children of the Empire', in Raising an Empire: Children in Early Modern Iberia and Colonial Latin America, ed. Ondina E. González and Bianca Premo (Albuquerque: University of New Mexico Press, 2007), 1-16.

77. Sankar Muthu, Enlightenment Against Empire (Princeton, NJ: Princeton University Press, 2003), 41.

78. Immanuel Kant, 'An Answer to the Question: What Is Enlightenment?', in Kant: Political Writings, ed. H.S. Reiss (Cambridge: Cambridge University Press, 1991), 54.

79. Ibid

80. See Mika LaVaque-Manty, 'Kant's Children', Social Theory and Practice 32, no. 3 (2006): 365-388, $369,380$.

81. Immanuel Kant, The Metaphysics of Morals, ed. Mary Gregor (Cambridge: Cambridge University Press, 2013), §46.

82. Immanuel Kant, On Education (Minneola, NY: Dover Press, 2003 [1899]), 14.

83. Ibid., 29.

84. Immanuel Kant, Political Writings, ed. H.S. Reiss (Cambridge: Cambridge University Press, 1991), 98 , footnote.

85. Ibid., 74.

86. J.S. Mill, On Liberty and Other Writings, ed. Stefan Collini (Cambridge: Cambridge University Press, 2003), 13. 'Nonage' is an out-of-use term for the age of minority, below the age of 21.

87. See Mehta, Liberalism and Empire, 32. See also 33, 35, 59-60, 70, 158.

88. Hegel, Phenomenology, 6-7.

89. G.W.F. Hegel, Philosophy of History, trans. J. Sibree (Mineola, NY: Dover), 106-8.

90. Hegel, Phenomenology, §28.

91. Auguste Comte, Introduction to Positive Philosophy, ed. Frederick Ferré (Indianapolis, IN: Hackett, 1988), 4. 
92. Myers, The Significance of Children and Animals, 37.

93. See Jean Piaget, The Language and Thought of the Child (New York: Meridian Press, 1955).

94. Stephen Jay Gould, Ontogeny and Phylogeny (Cambridge, MA: Harvard University Press, 1977), 130.

95. Richard A. Shweder, 'On Savages and Other Children', American Anthropologist 84, no. 2 (1982): 354-66, 354. See Ann Johnson, 'Constructing the Child in Psychology: The Child-as-Primitive in Hall and Piaget', Journal of Phenomenological Psychology 26, no. 2 (1995 Fall): 35-57.

96. Sigmund Freud, Totem and Taboo: Some Points of Agreement Between the Mental Lives of Savages and Neurotics (London: Routledge, 1999), x. It was the view of former student Erich Fromm that Freud depicted the child as 'a little criminal and a pervert.' Erich Fromm, The Crisis of Psychoanalysis: Essays on Freud, Marx, and Social Psychology (New York: Penguin, 1978), 63.

97. J. Henry, Third Report of the Board of Trustees of Public School of the District of Columbia (Washington, DC: R. Beresford, 1877), 115.

98. M. Eells, Annual Report of the Board of Indian Commissioners to the Secretary of the Interior (Washington, DC: Government Printing Office, 1878), 88.

99. J.F. Lister, Official Report of the Debates (Ottawa: Canadian House of Commons, 1885), 2012.

100. Glen Coulthard, Red Skin White Masks (Minneapolis: University of Minnesota Press, 2015).

101. Frantz Fanon, Black Skin White Masks, trans. Richard Philcox (New York: Grove Press, 2008), 135.

102. See Johnson, 'Constructing the Child', 37. For an account of the savage throughout history, first in the cyclical view, and then in linear progress, see Robert A. Williams Jr., Savage Anxieties: The Invention of Western Civilization (New York: Palgrave MacMillan, 2012). See also Hugh Cunningham, The Children of the Poor: Representations of Childhood since the Seventeenth Century (New York, Blackwell, 1991), 6.

103. See Leanne Simpson, Dancing on Our Turtle's Back (Peterborough, ON: Arbeiter Ring, 2011), 21.

\section{Disclosure statement}

No potential conflict of interest was reported by the author.

\section{Notes on contributor}

Toby Rollo is a Postdoctoral Fellow in the Department of Political Science at the University of British Columbia. His research explores conceptualizations of citizenship and political agency in western political thought, with a particular focus on problems related to colonial domination and exclusion. His published work on these issues includes "Mandates of the State: Canadian Sovereignty, Democracy, and Indigenous Claims," in the Canadian Journal of Law and Jurisprudence and a co-authored book chapter, "Settler Colonialism and the Consolidation of Canada in the Twentieth Century," in The Routledge Handbook of the History of Settler Colonialism. Dr. Rollo also researches how settler colonialism and democracy have been shaped by the figure of the voiceless child, which constitutes the perennial 'Other' in most western political ideals of agency. 